\title{
Predictive value of malignancy grading systems, DNA content, p53, and angiogenesis for stage I tongue carcinomas
}

\author{
Anders Högmo, Richard Kuylenstierna, Johan Lindholm, Eva Munck-Wikland
}

\begin{abstract}
Aim-To assess the clinical value of malignancy grading systems compared with nuclear DNA content, protein $\mathrm{p} 53$, and angiogenesis for predicting recurrence of stage I (UICC, 1987) tongue carcinomas. Methods-Histopathogical malignancy grading according to Jakobsson and tumour front grading according to Bryne et al were performed on haematoxylin and eosin slides. DNA analysis was performed by image cytometry. Protein p53 and angiogenesis were evaluated by immunohistochemical analysis using antibody CM1 and antibody against factor VIII related antigen, respectively.

Results-49 patients with stage I carcinomas of the mobile tongue were included, all treated by local surgical excision alone. Eight patients $(16 \%)$ suffered from local recurrence during follow up, and 13 (27\%) had regional recurrence. Both Jakobsson's malignancy grading system and p53 immunoreactivity proved to be useful predictors of regional recurrence in a Cox multivariate regression analysis.

Conclusions-Histopathological malignancy grading systems provide valuable prognostic information and can still compete with current biological markers in this respect.

(f Clin Pathol 1999;52:35-40)
\end{abstract}

Keywords: malignancy grading; protein $\mathrm{p} 53$; angiogenesis

The TNM classification according to the Union Internationale Contre le Cancer (UICC) or American Joint Committee on Cancer (AJCC) has long been the standard for classification of tumours, serving as a guideline for treatment of carcinomas of the head and neck. Furthermore, pathologists state their

Department of Oto-Rhino-Laryngology, Head and Neck Surgery, Karolinska Hospital, S-171 76 Stockholm, Sweden

A Högmo

R Kuylenstierna

E Munck-Wikland

Department of Tumour Pathology, Karolinska Hospital J Lindholm

Correspondence to: Dr Högmo.

Accepted for publication 4 September 1998 tumour cell characteristics and tumour-host relations were taken into account. ${ }^{2}$ This system was successfully applied by others, but has not been widely used, perhaps being too time consuming. ${ }^{3-5}$ Further development of Jakobsson's system has been done by Anneroth et al and by Bryne et al. ${ }^{67}$ Bryne's tumour front grading system - in which a small number of variables is applied only to the interface between the tumour and the host-has been shown to be useful prognostically, to be time effective, and to have good inter- and intraobserver reliability. ${ }^{8-10}$

Current research on prognostic factors has mainly concentrated on biological markers, for example changes in proto-oncogenes and tumour suppressor genes that lead to cellular transformation and tumour progression. $\mathrm{Nu}$ clear DNA content reflects the genetic instability of a tumour cell population and has been shown to have prognostic value for small head and neck tumours. ${ }^{11}$ Image cytometry (ICM) DNA analysis is a reproducible and easily applied method. Loss of p53 tumour suppressor function is considered to be the most commonly found genetic change in many solid tumours. Accumulation of the protein p53, usually the result of p53 gene mutation which causes a prolonged half life of the protein, can be detected by immunohistochemical staining (IHC) in about $30-70 \%$ of oral squamous cell carcinomas. However, the prognostic value of IHC p53 analysis shown by some investigators has been rejected by others. ${ }^{12-14}$

Nuclear DNA content and p53 immunostaining are both tumour cell related factors. However, interactions between the neoplastic cells and the host also play a crucial part in tumour development and progression. Tumour angiogenesis is an index of the tumour-host relation. Tumours induce their own neovascularisation and the vessels can be detected by immunohistochemical methods, for example by staining factor VIII related antigen in the endothelial walls. Some investigators have claimed that tumour angiogenesis is prognostically useful in different types of tumours, including head and neck cancer, while others have not found this to be so. ${ }^{13} 15-18$

Our aim in this study was to estimate the efficacy of malignancy grading in predicting the risk for recurrence, compared with image cytometry DNA analysis and immunohistochemical staining of p53 and factor VIII in stage I squamous cell carcinomas of the mobile tongue.

\section{Methods}

MATERIAL

Fifty four patients suffering from stage I (UICC, 1987) squamous cell carcinoma of the mobile tongue were collected from the files of 
Table 1 Malignancy grading system applied by fakobsson ${ }^{2}$

\begin{tabular}{|c|c|c|c|c|}
\hline \multirow[b]{2}{*}{ Tumour cell population } & \multicolumn{4}{|l|}{ Points assigned } \\
\hline & 1 & 2 & 3 & 4 \\
\hline Structure & Papillary and solid & Strands & Small cords and groups of cells & Marked cellular dissociation \\
\hline \multirow[t]{2}{*}{ Differentiation } & Highly: & Moderately: & Poorly: & Poorly: \\
\hline & Keratinisation & Some keratin & Minimum keratin & No keratinisation \\
\hline Nuclear polymorphism & Few enlarged nuclei & Moderate number & Numerous, irregular enlarged & Anaplastic, immature enlarged nuclei \\
\hline Mitoses & Single & Moderate number & Great number & Numerous \\
\hline \multicolumn{5}{|l|}{ Tumour-host relation } \\
\hline Mode of invasion & Well defined borderline & Cords, less marked borderline & $\begin{array}{l}\text { Groups of cells, no distinct } \\
\text { borderline }\end{array}$ & Diffuse growth \\
\hline Stage of invasion & Possibly & Microcarcinoma (few cords) & Nodular into connective tissue & Massive \\
\hline Vascular invasion & None & Possible & Few & Numerous \\
\hline Cellular response & Marked & Moderate & Slight & None \\
\hline
\end{tabular}

Table 2 Malignancy grading system applied by Bryne et al for evaluation of tumour front ${ }^{7}$

\begin{tabular}{|c|c|c|c|c|}
\hline & \multicolumn{4}{|l|}{ Points assigned } \\
\hline & 1 & 2 & 3 & 4 \\
\hline Degree of keratinisation & $\begin{array}{l}\text { Highly keratinised ( }>50 \% \text { of } \\
\text { cells) }\end{array}$ & $\begin{array}{l}\text { Moderately keratinised } \\
(20-50 \%)\end{array}$ & $\begin{array}{l}\text { Minimal keratinisation } \\
(5-20 \%)\end{array}$ & No keratin $(0-5 \%)$ \\
\hline Nuclear polymorphism & Little ( $>75 \%$ mature cells) & $\begin{array}{l}\text { Moderately abundant } \\
\text { nuclear polymorphism } \\
(50-75 \% \text { mature cells })\end{array}$ & $\begin{array}{l}\text { Abundant nuclear } \\
\text { polymorphism }(25-50 \% \\
\text { mature cells) }\end{array}$ & $\begin{array}{l}\text { Extreme nuclear polymorphism } \\
(0-25 \% \text { mature cells })\end{array}$ \\
\hline Pattern of invasion & $\begin{array}{l}\text { Pushing well delineated } \\
\text { infiltrating borders }\end{array}$ & $\begin{array}{l}\text { Infiltrating, solid cords, } \\
\text { bands and/or strands }\end{array}$ & $\begin{array}{l}\text { Small groups or cords of } \\
\text { infiltrating cells }(n>15)\end{array}$ & $\begin{array}{l}\text { Marked and widespread cellular } \\
\text { dissociation in small groups and/or in } \\
\text { single cells }(\mathrm{n}<15)\end{array}$ \\
\hline $\begin{array}{l}\text { Host response } \\
\quad \text { (infiltration of } \\
\text { leucocytes) }\end{array}$ & Marked & Moderate & Slight & None \\
\hline
\end{tabular}

the ENT department of Karolinska Hospital 1980-1990 and from a Swedish multicentre study, 1974-1986. Five patients were excluded because the specimens were unsatisfactory and not evaluable. Thus the study comprised 49 patients: 25 males, mean age 63 years (range 38 to 80 years), and 24 females, mean age 65 years (36 to 88 years).

The patients' records were reviewed for clinical data. All the patients were previously untreated. The single primary treatment for all tumours was a wedge excision, with at least a 1 $\mathrm{cm}$ macroscopic tumour-free margin. All the specimens included in this study had tumourfree margins. Mean follow up time was 68 months (median 66, range 6 to 175 months).

\section{LABORATORY PROCEDURES}

Three serial sections ( $4 \mu \mathrm{m}$ thick) were cut from archival formalin fixed, paraffin embedded specimens. The first section was stained with haematoxylin and eosin (H\&E) for histopathological analysis, and the second was stained according to the Feulgen technique for image cytometry DNA analysis. ${ }^{19}$

The third section was deparaffinised in xylene and passed through a graded ethanol series. These sections then underwent a 15 minute treatment with $0.05 \%$ protease (Labkemi/Sigma-Aldrich), and after blocking with $0.5 \% \mathrm{H}_{2} \mathrm{O}_{2}$ in water and $1 \%$ bovine serum albumin (BSA) in phosphate buffered saline (PBS), p53 rabbit polyclonal antibody CM1 (Novocastra) (1:700 in 1\% BSA) was added and the sections were incubated overnight at $4^{\circ} \mathrm{C}$ in a humidified chamber. After washing, the slides were incubated with biotinylated antirabbit IgG. A third layer of ABC Vectastain Kit Elite (Vector Laboratories) and diaminobenzidine (DAB) was added. Finally a weak counterstain was used to visualise the nuclei.
A fourth slide was prepared and developed in the manner described, but was stained for factor VIII related antigen (Dako).

\section{DNA measurement}

For quantitative DNA analysis, we used a densitometric device, the Ahrens image analysis system (Bargtheide). The DNA content of 100 nuclei per specimen was recorded. Lymphocytes were used as control cells to establish the normal diploid (2c) value. A DNA content between $2 \mathrm{c}$ and $4 \mathrm{c}$ is seen in premitotic normal cells, but DNA values exceeding $5 c$ are only rarely found in normal epithelial cells. Thus specimens containing $\geqslant 10 \%$ of cells with a DNA value exceeding $5 c$ were considered aneuploid (" 5 c exceeding rate," or $5 c E R)$.

Specimens with $<10 \%$ of the cells exceeding $5 \mathrm{c}$ but with $\geqslant 50 \%$ of the cells containing DNA values exceeding $2.5 \mathrm{c}$ were considered non-diploid. Specimens with $5 \mathrm{cER}<10 \%$ and $2.5 \mathrm{cER}<50 \%$ were considered diploid.

\section{p53 Staining}

The specimens were considered p53 positive $(+)$ when a distinct brown staining confined to the nuclei could be seen in at least $1 \%$ of the cells. For the p53 analysis, MDA 231 breast cancer cell line was used as external positive control. Non-tumour cells were used as internal negative control.

\section{Factor VIII}

All stained vessels were counted in a light microscope (HPF, 40x), in "hot spot" staining areas of the tumour tissue or in the closest adjacent area. The counting was performed on 10 visual fields and the mean count for each specimen was calculated (one visual field $=0.2 \times 0.2 \mathrm{~mm}$ ). 
Table 3 Grade of differentiation and recurrence

\begin{tabular}{lrrcl}
\hline & \multicolumn{1}{c}{$n$} & Well & Moderate & Poor \\
\hline Local recurrence & 8 & 4 & 2 & 2 \\
Regional recurrence & 13 & 5 & 7 & 1 \\
No recurrence & 28 & 15 & 12 & 1 \\
Total & 49 & 24 & 21 & 4 \\
\hline
\end{tabular}

Table 4 Results of IHC p53 and recurrence

\begin{tabular}{lrrrl}
\hline & & & & $\begin{array}{l}\text { IHC } \\
\text { error }\end{array}$ \\
& \multicolumn{1}{c}{$n$} & $p 53+$ & $p 53-$ & 5 \\
Local recurrence & 8 & 3 & 5 & 1 \\
Regional recurrence & 13 & 9 & 18 & 1 \\
No recurrence & 28 & 9 & 26 & 2 \\
Total & 49 & 21 & & \\
\hline
\end{tabular}

HISTOLOGICAL GRADING OF MALIGNANCY

The original method described by Jakobsson was used. ${ }^{2}$ In this system the tumour cell population is described by four different indices and graded in arbitrary units with a 1-4 point score. The same method is used for grading four indices of the tumour-host relation, and a total malignancy score is calculated (table 1).

Bryne's front grading system is based on the Jakobsson malignancy grading system and the indices used by Bryne (keratinisation, nuclear polymorphism, pattern of invasion, and host response) are also graded $1-4$ in arbitrary units and a total score calculated as a sum of these units (table 2). ${ }^{710}$ Reference images were used for the classifications. ${ }^{2}$

The variable "stage of invasion" of the Jakobsson system was estimated on two separate occasions by the same pathologist in order to evaluate the reproducibility. The pathologist also stated the grade of differentiation according to Broders, ${ }^{1}$ blinded to previous reports from the clinical records.

Table 5 Factors of Bryne tumour front and Fakobsson malignancy grading systems and results of IHC p53. Univariate analysis of regional recurrence, log rank test

\begin{tabular}{|c|c|c|c|c|c|c|}
\hline Factor & Points & $n$ & Recurrence & $\begin{array}{l}\text { Percent } \\
\text { recurrence }\end{array}$ & Log rank & p Value \\
\hline Structure & $\begin{array}{l}1 \\
2 \\
3 \\
4\end{array}$ & $\begin{array}{r}8 \\
18 \\
18 \\
5\end{array}$ & $\begin{array}{l}0 \\
3 \\
6 \\
4\end{array}$ & $\begin{array}{r}0 \\
17 \\
33 \\
80\end{array}$ & 13.24 & 0.004 \\
\hline Total & & 49 & & & & \\
\hline Mode of invasion & $\begin{array}{l}1 \\
2 \\
3 \\
4\end{array}$ & $\begin{array}{r}10 \\
18 \\
18 \\
3 \\
49\end{array}$ & $\begin{array}{l}0 \\
5 \\
5 \\
3\end{array}$ & $\begin{array}{r}0 \\
28 \\
28 \\
100\end{array}$ & 16.64 & 0.0008 \\
\hline Stage of invasion & $\begin{array}{l}1 \\
2 \\
3 \\
4\end{array}$ & $\begin{array}{r}4 \\
7 \\
36 \\
2 \\
49\end{array}$ & $\begin{array}{r}0 \\
0 \\
11 \\
2\end{array}$ & $\begin{array}{r}0 \\
0 \\
31 \\
100\end{array}$ & 8.61 & 0.035 \\
\hline Vascular invasion & $\begin{array}{l}1 \\
2 \\
3 \\
4\end{array}$ & $\begin{array}{r}14 \\
35 \\
0 \\
0 \\
49\end{array}$ & $\begin{array}{r}0 \\
13 \\
0 \\
0\end{array}$ & $\begin{array}{r}0 \\
37 \\
0 \\
0\end{array}$ & 6.33 & 0.012 \\
\hline $\begin{array}{l}\text { p53 } \\
\text { Total }\end{array}$ & $\begin{array}{l}+ \\
-\end{array}$ & $\begin{array}{l}21 \\
26 \\
47\end{array}$ & $\begin{array}{l}9 \\
3\end{array}$ & $\begin{array}{l}43 \\
12\end{array}$ & 5.11 & 0.024 \\
\hline $\begin{array}{l}\text { Bryne nuclear } \\
\text { polymorphism }\end{array}$ & $\begin{array}{l}1 \\
2 \\
3 \\
4\end{array}$ & $\begin{array}{r}16 \\
20 \\
7 \\
6 \\
49\end{array}$ & $\begin{array}{l}1 \\
6 \\
4 \\
2\end{array}$ & $\begin{array}{r}6 \\
30 \\
57 \\
33\end{array}$ & 7.74 & 0.052 \\
\hline
\end{tabular}

STATISTICAL METHODS

To evaluate of the risk of recurrence (local: recurrence in the tongue; regional: cervical metastases; any: local or regional recurrence) the log rank test was used for univariate statistical analysis of categorical data from the malignancy grading systems, nuclear DNA content expressed as ploidy, and p53 immunostaining. For the quantitative variables (2.5cER, 5cER, factor VIII, and Jakobsson's and Bryne's malignancy grading system scores), the Cox regression analysis was applied. Time to recurrence (local, regional, any recurrence) was used for these analyses, and was estimated as the time from diagnosis to when a recurrence was verified through a biopsy or fine needle aspiration cytology.

All data that appeared to have any predictive value after the univariate analysis were then included in the Cox multivariate regression analysis to evaluate which factor had the greatest influence on recurrence. The level of statistical significance was set to $\mathrm{p}=0.05$. The Pearson correlation coefficient was used for evaluation of intra- and interobserver variations.

\section{Results}

Eight of 49 patients (16\%) had a local recurrence and 13 had regional recurrence (27\%) (table 3).

\section{TIME TO RECURRENCE}

Mean time to local recurrence was 27 months (range 11 to 55 months) and for regional recurrence 12 months (3 to 40 months).

\section{GRADE OF DIFFERENTIATION}

Table 3 shows the grade of differentiation of the 49 carcinomas. Only four were poorly differentiated $(8 \%)$ while there was equal distribution of moderately and well differentiated tumours.

Univariate and multivariate statistical analysis of either the original or the re-evaluated grade of differentiation (see below) yielded no significant information about the recurrence risk.

p53 IMMUNOSTAINING

The results of p53 immunostaining for recurring and non-recurring tumours are shown in table 4 .

ANGIOGENESIS

In 41 of the 49 cases staining for factor VIII related antigen was evaluable. Angiogenesis had no statistically significant impact on prediction of recurrence.

UNIVARIATE AND MULTIVARIATE ANALYSIS OF MALIGNANCY GRADING SYSTEMS AND BIOLOGICAL MARKERS

All factors were evaluated in a univariate analysis (log rank test or Cox regression analysis) for risk of local, regional, or any kind of recurrence (local or regional).

\section{Regional recurrence}

The results of the univariate analysis of the malignancy grading factors and IHC p53 (categorical data) are shown in table 5 (log rank test). 
Table 6 Univariate Cox regression analysis of regional recurrence

\begin{tabular}{llllll}
\hline Factor & $n$ & $B$ & $S E$ & $R H$ & $p$ Value \\
\hline F VIII & 41 & 0.0450 & 0.0785 & 1.046 & 0.567 \\
Score 1 & 49 & 0.2281 & 0.0841 & 1.2562 & 0.0067 \\
Score 2 & 49 & 0.2050 & 0.1010 & 1.2275 & 0.0423 \\
2.5 cER & 49 & 0.0078 & 0.0156 & 1.0079 & 0.6162 \\
5cER & 49 & 0.0230 & 0.0229 & 1.0232 & 0.3159 \\
\hline
\end{tabular}

Score 1 = Jakobsson malignancy grading; score $2=$ Bryne tumour front grading system. ER, exceeding rate.

Table 7 Multvariate Cox regression analysis: regional recurrence. Relative hazards $(R H)$ and $95 \%$ confidence intervals (CI); the other competing factor was Bryne front grading score

\begin{tabular}{lrllll}
\hline Factor & \multicolumn{1}{l}{$B$} & $S E$ & $R H$ & \multicolumn{1}{l}{$C I$} & \multicolumn{1}{l}{ RI } \\
\hline Jakobsson's score & 0.221 & 0.088 & 1.25 & $1.05-1.48$ & 0.012 \\
p53 & -1.371 & 0.668 & 0.25 & $0.07-0.94$ & 0.040 \\
\hline
\end{tabular}

Table 8 Factors of Bryne tumour front and Fakobsson malignancy grading systems and results of ploidy: univariate analysis of local or regional recurrence, log rank test

\begin{tabular}{|c|c|c|c|c|c|c|}
\hline Factor & Points & $n$ & Recurrence & $\begin{array}{l}\text { Percent } \\
\text { recurrence }\end{array}$ & Log rank & $p$ Value \\
\hline Structure & $\begin{array}{l}1 \\
2 \\
3 \\
4\end{array}$ & $\begin{array}{r}8 \\
18 \\
18 \\
5\end{array}$ & $\begin{array}{l}3 \\
7 \\
6 \\
5\end{array}$ & $\begin{array}{r}37 \\
39 \\
33 \\
100\end{array}$ & 11.63 & 0.0087 \\
\hline Total & & 49 & & & & \\
\hline Mode of invasion & $\begin{array}{l}1 \\
2 \\
3 \\
4\end{array}$ & $\begin{array}{r}10 \\
18 \\
18 \\
3\end{array}$ & $\begin{array}{r}5 \\
10 \\
5 \\
1\end{array}$ & $\begin{array}{r}30 \\
39 \\
44 \\
100\end{array}$ & 10.13 & 0.0175 \\
\hline Total & & 49 & & & & \\
\hline Stage of invasion & $\begin{array}{l}1 \\
2 \\
3 \\
4\end{array}$ & $\begin{array}{r}4 \\
7 \\
36 \\
2 \\
49\end{array}$ & $\begin{array}{r}0 \\
1 \\
18 \\
2\end{array}$ & $\begin{array}{r}0 \\
14 \\
50 \\
100\end{array}$ & 7.80 & 0.0504 \\
\hline $\begin{array}{l}\text { Aneuploid } \\
\text { Non-diploid } \\
\text { Diploid } \\
\text { Total }\end{array}$ & & $\begin{array}{r}32 \\
11 \\
6 \\
49\end{array}$ & $\begin{array}{r}18 \\
1 \\
2\end{array}$ & $\begin{array}{r}56 \\
9 \\
33\end{array}$ & 6.84 & 0.0327 \\
\hline $\begin{array}{l}\text { Bryne nuclear } \\
\text { polymorphism }\end{array}$ & $\begin{array}{l}1 \\
2 \\
3 \\
4\end{array}$ & $\begin{array}{r}16 \\
20 \\
7 \\
6 \\
49\end{array}$ & $\begin{array}{r}2 \\
12 \\
4 \\
3\end{array}$ & $\begin{array}{l}12 \\
60 \\
57 \\
50\end{array}$ & 8.64 & 0.0345 \\
\hline
\end{tabular}

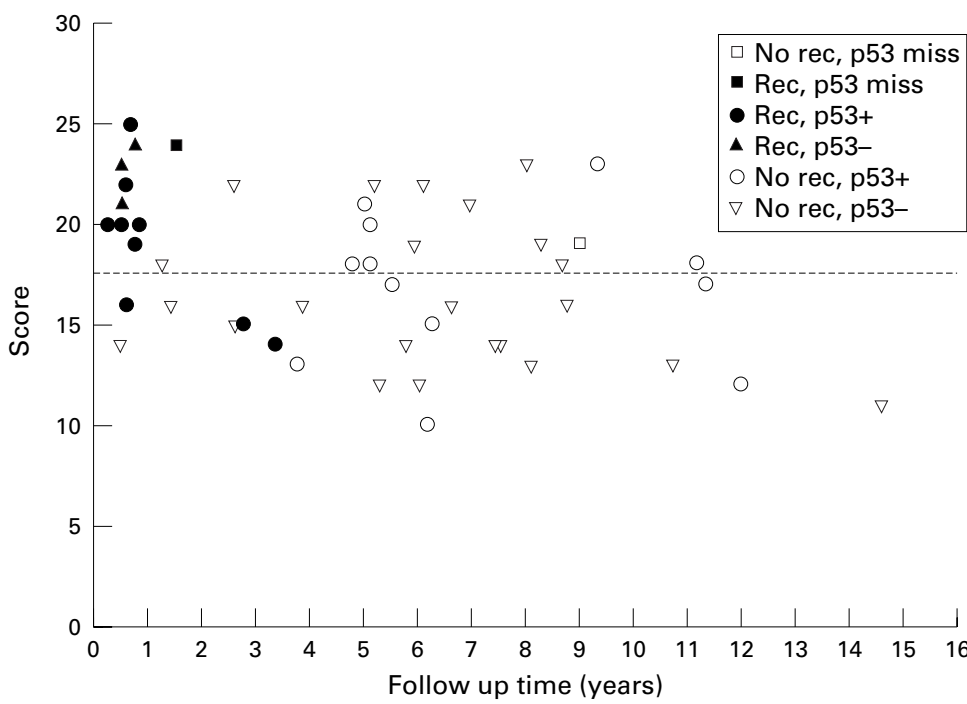

Figure 1 Regional recurrence $(n=13)$ in relation to Fakobsson's malignancy grade and p53 expression for each case. Dotted line indicates the malignancy score of 17.5 points; exact mean of the score $=17.633$.
The results of the univariate analysis of the continuous variables (malignancy scores, $2.5 \mathrm{cER}, 5 \mathrm{cER}$, and IHC factor VIII) are shown in table 6 (Cox regression analysis). The multivariate evaluation is shown in table 7 (Cox multivariate regression analysis).

In the univariate analysis, tumours that later developed regional recurrence showed a more pronounced cellular dissociation in their structure, a more diffuse and massive mode and stage of invasion, and more numerous invading vessels than tumours without regional recurrence.

Overexpression of p53 also correlated with regional recurrence. Finally, nuclear polymorphism, as used by Bryne, tended to be more pronounced in tumours prone to regional recurrence.

Both of the malignancy grading systems were superior to DNA analysis and IHC factor VIII for predicting regional recurrence (table 6).

Factors that were significant in the univariate tests were selected to compete in a Cox multivariate regression analysis. For predicting regional recurrence, the multivariate analysis showed that $\mathrm{p} 53$ positivity and Jakobsson score were highly significant, the latter being somewhat superior (table 7).

The relations between Jakobsson malignancy score, IHC p53, and regional recurrence are shown in fig 1 . In 35 of the 49 cases $(71 \%)$ the score was more than 17.5 and/or immunostaining of p53 was positive. Thirteen of these patients developed a regional recurrence (13/ $49=27 \%)$ and 22 patients $(22 / 49=45 \%)$ did not. Fourteen of the 49 patients $(29 \%)$ had a malignancy score of $<17.5$ and negative IHC p53. None of these patients had regional recurrence.

\section{Local recurrence}

Local recurrence was analysed by the same statistical methods. Here, tumours with less marked cellular dissociation (structure, Jakobsson system) showed a higher frequency of local recurrence than tumours without local recurrence ( $\mathrm{p}=0.042, \log$ rank test).

Any (local or regional) recurrence-The results of the univariate analysis of the categorical variables are shown in table 8 (log rank test). For prediction of any kind of recurrence (local or regional) both the tumour cell related factor-structure-and tumour-host related factors-mode and stage of invasion of the Jakobsson system-showed statistical significance. Once again, the factor "nuclear polymorphism" in the Bryne front grading system was significant.

Ploidy also predicted any kind of recurrence, while p53 immunoreactivity did not. Among the continuous factors, only the Jakobsson score was close to significance ( $p=0.0605$, Cox regression analysis). In the multivariate analysis, no factor was superior (Jakobsson score, ploidy).

\section{TESTS OF REPRODUCIBILITY}

Grade of differentiation, according to Broders, was re-evaluated and the result of this was compared with the original histopathological 
assessment. Forty three of the 49 tumours were given the same grade of differentiation $(88 \%)$. The (interobserver) correlation was $r=0.83$ ( $\mathrm{p}<0.001$, Pearson correlation).

In a similar manner, the variable "stage of invasion" from the Jakobsson system was blindly evaluated twice by the same pathologist. Thirty six of the 49 cases $(73 \%)$ were given the same arbitrary unit on both evaluations using the same H\&E slides. The (intraobserver) correlation was $r=0.68(\mathrm{p}<0.001$, Pearson correlation). The difference between the first and the second evaluation was never more than 1 arbitrary unit.

\section{Discussion}

Squamous cell carcinoma of the head and neck shows significant variation in aggressiveness. Small tongue cancers have occult metastasis in the neck in about $30 \%$ of cases and the overall recurrence rate of $43 \%$ found in the present investigation is in accordance with other studies. ${ }^{2021}$ For local tumour control, the resection must be done with sufficient margins. Furthermore, since occult metastases are so frequent, most patients get adjuvant treatment of the neck (either neck dissection or radiotherapy). However, if we could identify the tumours prone to metastasise regionally, a proportion of these patients could be spared the morbidity caused by adjuvant neck treatment.

In the search to refine the prediction of aggressiveness in individual tumours, different biological markers and malignancy grading systems have been used. Malignancy grading systems are attempts to standardise the otherwise subjective histomorphological verdict. In the last decade or so molecular biological techniques have attracted the most interest and an immense amount of information has been obtained from these studies. Single or multiple markers have been found to provide information on prognosis, but we are still awaiting the hoped-for clinical breakthrough with these methods. Thus it is still relevant to make critical comparisons between molecular biological markers and the different histological scoring systems, not to mention the possibilities of combining these methods. ${ }^{22}$

Our present material meets the important prerequisites for such comparisons, since the tumours were all located at the same anatomical site, all were of the same size (T1N0M0), and all were uniformly treated. ${ }^{68}$ Our study showed that the Jakobsson malignancy grading system had significant prognostic value for predicting regional recurrence, while conventional differentiation grading did not. In the univariate analysis the Jakobsson factors "structure," "mode of invasion," and "vascular invasion" had considerable impact. These factors seem to be logical correlates of tumour aggressiveness.

The presence of p53 immunoreactivity also suggested an increased risk of regional recurrence (fig 1). The p53 gene is coupled with cell cycle control. Wild-type p53 causes cell cycle arrest in order to repair DNA damage, and in the case of irreparable DNA damage it induces apoptosis. Loss of p53 tumour suppressor function may lead to a clonal expansion of cells lacking normal control mechanisms, and, together with other defects of the genome, cause early spread of cells with defective p53 function.

Local recurrence could not be predicted from the results. Local recurrence is subject to methodological errors such as variations in surgical technique and decisions on macroscopical tumour margins and not only to the biological behaviour of the tumour cells.

Ploidy had an impact on any (local or regional) recurrence in the univariate analysis. Earlier investigations have shown similar results. $^{9112324}$ Zätterström et al found that ploidy was of prognostic value for survival in the univariate model and, in accordance with our present investigation, of limited importance in multivariate analysis. ${ }^{24}$

DNA measurements and p53 immunostaining are tumour related factors and do not tell us anything about tumour-host interactions. Local tumour growth, beyond a certain number of cells, and the development of regional and distant metastases both depend on access to the blood circulation. ${ }^{25}$ Angiogenesis has been shown to have prognostic significance in various tumours, but for head and neck cancer the results have been conflicting. ${ }^{26}$ However, most studies have involved tumours originating from different sites and of different stages, and this may have distorted the results. Different methods have been used as well. ${ }^{15-17} 27{ }^{28}$ In the current study, we found that evaluation of angiogenesis provided no useful information about recurrence risk.

We found that the Jakobsson score was as good as p53 immunostaining for predicting regional recurrence. It is worth bearing in mind that p53 immunostaining is considerably more time consuming and expensive than the extended evaluation of microscope specimens in any malignancy grading system performed on H\&E stained slides.

The Bryne tumour front grading system had no prognostic impact in our study, although it has been successfully applied by others. ${ }^{89}$ This might have been because this was the first time we had used the method, while we had some previous experience of the use of the Jakobsson system.

The reproducibility of malignancy grading systems could be improved, as pointed out by Bryne et al. ${ }^{29}$ Since the reproducibility and the results of each single factor could be questioned (for example, the different results for the tumour cell population related factor, "structure"), we chose to exclude single factors from the multivariate Cox regression model in this study. However, we showed that a thorough histological evaluation of the tumour specimens in a regular and reproducible way can, when relevant criteria are examined, provide prognostic information of significant value. Such efforts to refine histopathology are still important and histopathological assessments can still compete with biological markers.

This investigation was based upon a unique collection of stage I squamous cell carcinomas of the mobile tongue, as all patients had been 
treated with only local excision, without any treatment of the neck. Local control of the disease depends largely on surgical margins. The regional recurrences, however, which were found in $27 \%$ of our patients, raise the important issue of adjuvant treatment of the neck. If a decision about neck treatment for these patients had been based on the results of the Jakobsson malignancy grading system and IHC p53 - that is, patients with tumours showing a high malignancy grading score and/or p53 immunoreactivity - all patients who needed adjuvant neck treatment would have been given it. Forty five per cent of the patients, instead of $73 \%$, would have been overtreated but nearly one third (29\%) of the patients could have been spared unnecessary neck treatment (fig 1).

CONCLUSIONS

For predicting regional recurrence (cervical metastases) in stage I squamous cell carcinoma of the mobile tongue, the Jakobsson malignancy grading system and IHC p53 showed, independently, significant values in a Cox multivariate regression analysis. The clinical value of combining histopathological malignancy grading with biological markers, as in this study, should be further investigated.

This study was supported by grants from Cancerfonden (2992-B94-04xBC) and Cancerföreningen i Stockholm. We wish
to thank Ms A-B Wikström for valuable technical assistance and to thank Ms A-B Wikström for valuable technical assistance and Mr B Nilsson, Department of Cancer Epidemiology, Radium-
hemmet, Karolinska Hospital, for help with statistical interpretation.

1 Broders A. The microscopic grading of cancer. Surg Clin North Am 1941;21:947-62.

2 Jacobsson P. Glottic carcinoma of the larynx-factors influencing prognosis following radiotherapy. Stockholm: Karolinska Institute, 1973 [thesis].

3 Holm L-E, Lundquist P-G, Silfverswärd C, et al. Histological grading of malignancy in squamous cell carcinoma of the oral tongue. Acta Otolaryngol 1982;94:185-92.

4 Willén R, Nathanson A, Moberger G, et al. Squamous cell carcinoma of the gingiva. Histological classification and grading of malignancy. Acta Otolaryngol 1975;79:146-54.

5 Nason R, Castillo N, Sako K, et al. Cervical node metastasis in early squamous cell carcinoma of the floor of the mouth: predictive value of multiple histopathologic parameters. World f Surg 1990;14:606-9.

6 Anneroth G, Batsakis J, Luna M. Review of the literature and a recommended system of malignancy grading in oral a recommended system of malignancy grading in oral 49 .

7 Bryne M, Koppang HS, Lilleng R, et al. New malignancy grading is better a prognostic indicator than Broder's grading in oral squamous cell carcinomas. F Oral Pathol Med 1989;18:432-7.
8 Odell E, Jani P, Sherriff M, et al. The prognostic value of individual histologic grading parameters in small lingual

9 Welkoborsky H-J, Hinni M, Dienes H-P, et al. Predicting recurrence and survival in patients with laryngeal cancer by means of DNA cytometry, tumor front grading and proliferation markers. Ann Otol Rhinol Laryngol 1995;104:50310.

10 Bryne M, Koppang H, Lilleng R, et al. Malignancy grading of the deep invasive margins of oral squamous cell carcinoof the deep invasive margins of oral squamous cell carcino-

11 Munck-Wikland E, Kuylenstierna R, Lind M, et al. The prognostic value of cytometric DNA analysis in early stage tongue cancer. Oral Oncol Eur f Cancer 1992;28B:135-8.

12 Gluckman JL, Stambrook PJ, Pavelic ZP. Prognostic significance of $\mathrm{p} 53$ protein accumulation in early stage $\mathrm{T} 1$ oral cavity cancer. Oral Oncol Eur f Cancer 1994;30B:281.

13 Leedy DA, Trune DR, Kronz JD, et al. Tumour angiogenesis, the p53 antigen, and cervical metastasis in squamous
cell carcinoma of the tongue. Otolaryngol Head Neck Surg 1994;111:417-22.

14 Shin D, Lee J, Lippman S, et al. p53 expression: predicting recurrence and secondary primary tumors in head and neck squamous cell carcinoma. F Natl Cancer Inst 1996;88: 519-29.

15 Williams JK, Carlson G, Cohen C, et al. Tumour angiogenesis as a prognostic factor in oral cavity tumors. Am $\mathcal{F}$ Surg 1994;168:373-80.

16 Alcalde R, Shintani S, Yoshihama Y, et al. Cell proliferation and tumor angiogenesis in oral squamous cell carcinoma. Anticancer Res 1995;15:1417-22.

17 Dray T, Hardin N, Sofferman R. Angiogenesis as a prognostic marker in early head and neck cancer. Ann Otol Rhinol Laryngol 1995;104:724-9.

18 Hedge P, Brenski A, Caldarelli D, et al. Tumour angiogenesis and p53 mutations. Prognosis in head and neck cancer. Arch Otolaryngol Head Neck Surg 1998;124:80-5.

19 Auer G, Askensten U, Ahrens O. Cytophotometry. Hum Pathol 1989;20:518-27.

20 Spiro RH, Strong EH. Epidermoid carcinoma of the mobile tongue treated by partial glossectomy alone. Am f Surg 1971;122:707-10.

21 Yuen A, Wei W, Wong Y, et al. Elective neck dissection verus observation in the treatment of early oral tongue carcinoma. Head Neck 1997;19:583-8.

22 Piffkò J, Bànkfalvi À, Tory K, et al. Molecular assessment of p53 abnormalities at the invasive front of oral squamous cell carcinomas. Head Neck 1998;20:8-15.

23 Tytor M, Olofsson J, Ledin $\mathrm{T}$, et al. Squamous cell carcinoma of the oral cavity. A review of 176 cases with application of malignancy grading and DNA measurements. Clin Otolaryngol 1990;15:235-51.

24 Zätterström U, Wennerberg J, Ewers SB, et al. Prognostic factors in head and neck cancer: Histologic grading, DNA ploidy and nodal status. Head Neck 1991;13:477-87.

25 Folkman J. What is the evidence that tumors are angiogenesis dependent? F Natl Cancer Inst 1990;82:4-6.

26 Weidner N. Intratumor microvessel density as a prognostic factor in cancer. Am ₹ Pathol 1995;147:9-19.

27 Gasparini G, Weidner N, Maluta S, et al. Intratumoral microvessel density and p53 protein: correlation with metastasis in head-and-neck squamous-cell carcinoma. Int f Cancer 1993;55:739-44.

28 Gluckman JL, Pavelic ZP, Welkoborsky H-J, et al. Prognostic indicators for squamous cell carcinoma of the oral cavity: a clinicopathologic correlation. Laryngoscope 1997; 107:1239-44.

29 Bryne M, Nielsen K, Koppang HS, et al. Reproducibility of two malignancy grading systems with reportedly prognostic value for oral cancer patients. I Oral Pathol Med 1991;20:369-72. 